\title{
Identification of Foods To Monitor The Sodium Content of Processed Foods for Developing a Sodium Reduction Program in The Philippines
}

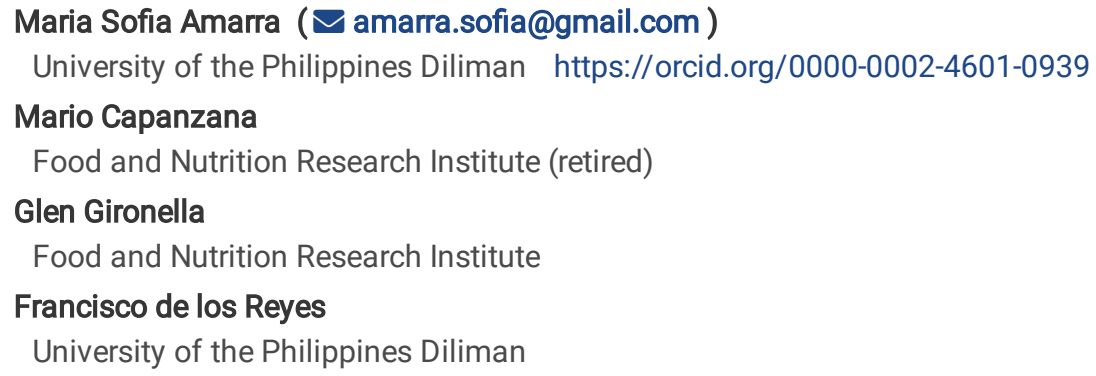

\section{Research}

Keywords: sodium, salt intake, dietary sources, Philippines, salt reduction, per capita

Posted Date: November 1st, 2021

DOI: https://doi.org/10.21203/rs.3.rs-903177/v2

License: (c) (i) This work is licensed under a Creative Commons Attribution 4.0 International License. Read Full License 


\section{Abstract \\ Background}

In response to the global target for reduction in salt intake, several countries have implemented population sodium reduction strategies. These strategies include identification of major sources of sodium in the diet and reformulation of a set number of products available on the market. This study aimed to identify processed foods that can be targeted for reformulation and whose sodium content can be monitored over time in order to reduce sodium intake in the Philippines. The objectives were to: 1 ) Estimate per capita sodium intake from minimally processed and processed food groups by income quintile and urban/rural location; 2) Identify foods that contribute to the variance in per capita sodium intake that can be used as indicators for monitoring the sodium content of Philippine processed foods. One-day household food weighing data covering 4880 households from the 2008 National Nutrition Survey was used. Per capita sodium consumption from processed and minimally processed food categories and percentiles of sodium intake from these categories by income quintile and urban/rural location were obtained. The percentage contribution of different food categories to mean per capita sodium intake was calculated. Specific foods that contributed to the variance in sodium intake among Filipinos were identified.

\section{Results}

Foods which significantly accounted for $99.4 \%$ of the variance in sodium intake were 13 types of processed foods and 2 types of minimally processed foods. The category Processed Soup, Sauces, and Flavor Enhancers contributed the greatest proportion to per capita sodium intake. Specific processed foods that contributed to the variance in per capita sodium intake were instant noodles, traditional fermented condiments and sauces, dried and processed meat, fish, and poultry products, salted eggs, white bread and pan de sal (a traditional Filipino bread), wheat and egg noodles, crispy cereal chips and extruded snacks, butter and margarine, cheese, and chocolate-based beverages.

\section{Conclusion}

Identifying processed foods that significantly contribute to sodium intake, followed by reformulating and monitoring the sodium content of these foods over time should be considered as one strategy to reduce sodium intake in the Philippines.

\section{Background}

Hypertension is a risk factor for cardiovascular disease driven by excess dietary salt intake. The WHO Global Action Plan for the Prevention and Control of Noncommunicable Diseases 2013-2020 [1] set voluntary targets for achievement in 2025 by its Member States, including "a $30 \%$ relative reduction in mean population intake of salt/sodium $(\mathrm{Na})$ " towards the recommended level of $2000 \mathrm{mg} \mathrm{Na} /$ day $(5 \mathrm{~g} \mathrm{salt} / \mathrm{day}$ ). This can be achieved by developing "guidelines, recommendations or policy measures that engage different relevant sectors, such as food producers and processors, and other relevant commercial operators, as well as consumers, to reduce the level of salt/sodium added to food (prepared or processed) [1]." In response to the global target for reduction in salt intake, several countries have implemented population sodium reduction strategies. These strategies include identification of major sources of sodium in the diet and reformulation of a set number of products available on the market [2]. In the United States, a sodium monitoring program led by USDA tracks "sentinel foods" i.e., foods that contribute to sodium intake in the population and are used as indicators to track changes in the sodium content of processed foods [3]. Since most sodium in the diet comes from processed foods, reducing the amount of sodium in sentinel foods will translate into reduced sodium intake at the population level. The present study aimed to identify processed foods that can be targeted for reformulation to reduce sodium intake among Filipinos, using one-day household food weighing data from the 2008 National Nutrition Survey. The objectives were to: 1) Estimate per capita sodium intake from minimally processed and processed food groups by income quintile and urban/rural location; 2) Identify foods that significantly contribute to the variance in per capita sodium intake among Filipinos which can potentially serve as indicator foods to monitor the sodium content of processed foods.

\section{Results}

\section{a. Per capita sodium intake from different food categories}

Table 1 shows the mean per capita sodium intake and percentile distribution of sodium intake from minimally processed and processed food groups. Mean per capita intake exceeded the WHO recommendation of $2000 \mathrm{mg}$ sodium, with rural households ingesting more sodium than urban households. Median sodium intake was highest for Processed Soup, Sauces \& Flavor Enhancers, with half of the population consuming $>1416 \mathrm{mg} \mathrm{Na}$ from this food category alone. Median intake was highest among the highest income households. 
Table 1

Mean per capita intake by urban/rural location and percentile distribution of sodium (mg/day) ingested from minimally processed and processed food groups by income quintile and urban/rural location

\begin{tabular}{|c|c|c|c|c|c|c|c|c|c|c|c|c|c|c|c|}
\hline & \multicolumn{15}{|c|}{ Per capita Na intake (mg/day) } \\
\hline & \multicolumn{5}{|c|}{ Urban } & \multicolumn{5}{|c|}{ Rural } & \multicolumn{5}{|l|}{ Both } \\
\hline Mean \pm SE & \multicolumn{5}{|c|}{$2767 \pm 57$} & \multicolumn{5}{|c|}{$2862 \pm 68$} & \multicolumn{5}{|c|}{$2813 \pm 44$} \\
\hline $\begin{array}{l}\text { Minimally } \\
\text { processed } \\
\text { foods }\end{array}$ & P25 & P50 & P75 & P99 & IQR & P25 & P50 & P75 & P99 & IQR & P25 & P50 & P75 & P99 & IQR \\
\hline \multicolumn{16}{|l|}{$\begin{array}{l}\text { A. Fish, } \\
\text { meat, } \\
\text { poultry }\end{array}$} \\
\hline $\begin{array}{l}\text { - Q1 } \\
\text { (lowest) }\end{array}$ & 3 & 24 & 62 & 547 & 59 & 0 & 18 & 56 & 693 & 56 & 0 & 18 & 56 & 675 & 56 \\
\hline - Q2 & 24 & 49 & 105 & 597 & 81 & 10 & 43 & 93 & 730 & 83 & 17 & 45 & 95 & 713 & 79 \\
\hline - Q3 & 34 & 64 & 124 & 776 & 89 & 25 & 58 & 118 & 585 & 94 & 30 & 61 & 121 & 756 & 91 \\
\hline - Q4 & 42 & 80 & 141 & 637 & 99 & 44 & 95 & 173 & 953 & 129 & 43 & 87 & 150 & 784 & 107 \\
\hline $\begin{array}{l}\text { - Q5 } \\
\text { (highest) }\end{array}$ & 63 & 107 & 175 & 869 & 112 & 67 & 110 & 189 & 1173 & 123 & 64 & 108 & 176 & 880 & 112 \\
\hline $\begin{array}{l}\text { - All wealth } \\
\text { quintiles }\end{array}$ & 38 & 77 & 139 & 756 & 101 & 10 & 48 & 105 & 846 & 95 & 24 & 62 & 125 & 776 & 101 \\
\hline \multicolumn{16}{|l|}{$\begin{array}{l}\text { B. Rice, } \\
\text { cereals, } \\
\text { starches }\end{array}$} \\
\hline - Q1 & 50 & 76 & 101 & 240 & 51 & 53 & 87 & 114 & 244 & 61 & 53 & 86 & 112 & 244 & 60 \\
\hline - Q2 & 60 & 76 & 104 & 192 & 44 & 62 & 85 & 115 & 244 & 53 & 62 & 81 & 110 & 207 & 48 \\
\hline - Q3 & 60 & 78 & 101 & 194 & 41 & 62 & 82 & 110 & 190 & 47 & 61 & 80 & 106 & 193 & 45 \\
\hline - Q4 & 58 & 74 & 95 & 187 & 37 & 61 & 81 & 113 & 319 & 52 & 58 & 76 & 100 & 219 & 42 \\
\hline - Q5 & 51 & 68 & 88 & 170 & 38 & 51 & 78 & 100 & 279 & 49 & 51 & 69 & 92 & 205 & 41 \\
\hline - All & 56 & 73 & 96 & 193 & 40 & 59 & 84 & 112 & 239 & 53 & 57 & 78 & 104 & 213 & 47 \\
\hline \multicolumn{16}{|l|}{$\begin{array}{l}\text { C. } \\
\text { Vegetables } \\
\text { \& fruits }\end{array}$} \\
\hline - Q1 & 2 & 4 & 15 & 90 & 13 & 2 & 8 & 17 & 128 & 16 & 2 & 7 & 17 & 105 & 15 \\
\hline - Q2 & 1 & 5 & 13 & 131 & 11 & 2 & 8 & 19 & 82 & 17 & 2 & 7 & 16 & 119 & 15 \\
\hline - Q3 & 3 & 7 & 15 & 72 & 12 & 3 & 7 & 16 & 125 & 13 & 3 & 7 & 15 & 91 & 12 \\
\hline - Q4 & 3 & 9 & 17 & 85 & 13 & 4 & 10 & 21 & 112 & 17 & 3 & 9 & 18 & 94 & 15 \\
\hline - Q5 & 4 & 10 & 20 & 104 & 15 & 4 & 10 & 21 & 120 & 16 & 4 & 10 & 20 & 104 & 16 \\
\hline - All & 3 & 8 & 16 & 90 & 13 & 3 & 8 & 18 & 125 & 16 & 3 & 8 & 17 & 104 & 14 \\
\hline \multicolumn{16}{|l|}{ D. Milk } \\
\hline - Q1 & 0 & 0 & 0 & 48 & 0 & 0 & 0 & 0 & 55 & 0 & 0 & 0 & 0 & 55 & 0 \\
\hline - Q2 & 0 & 0 & 1 & 69 & 1 & 0 & 0 & 0 & 81 & 0 & 0 & 0 & 0 & 78 & 0 \\
\hline - Q3 & 0 & 0 & 8 & 90 & 8 & 0 & 0 & 2 & 76 & 2 & 0 & 0 & 6 & 79 & 6 \\
\hline - Q4 & 0 & 0 & 8 & 138 & 8 & 0 & 0 & 14 & 77 & 14 & 0 & 0 & 9 & 106 & 9 \\
\hline - Q5 & 0 & 0 & 12 & 134 & 12 & 0 & 0 & 9 & 101 & 9 & 0 & 0 & 12 & 131 & 12 \\
\hline - All & 0 & 0 & 8 & 118 & 8 & 0 & 0 & 0 & 73 & 0 & 0 & 0 & 5 & 90 & 5 \\
\hline
\end{tabular}




\begin{tabular}{|c|c|c|c|c|c|c|c|c|c|c|c|c|c|c|c|}
\hline \multirow{3}{*}{\begin{tabular}{|l|} 
\\
\\
$\begin{array}{l}\text { E. Beans, } \\
\text { nuts, } \\
\text { seeds }\end{array}$ \\
\end{tabular}} & \multicolumn{15}{|c|}{ Per capita Na intake (mg/day) } \\
\hline & \multicolumn{5}{|c|}{ Urban } & \multicolumn{5}{|c|}{ Rural } & \multicolumn{5}{|l|}{ Both } \\
\hline & & & & & & & & & & & & & & & \\
\hline - Q1 & 0 & 0 & 0 & 9 & 0 & 0 & 0 & 0 & 7 & 0 & 0 & 0 & 0 & 7 & 0 \\
\hline - Q2 & 0 & 0 & 0 & 8 & 0 & 0 & 0 & 0 & 8 & 0 & 0 & 0 & 0 & 8 & 0 \\
\hline - Q3 & 0 & 0 & 0 & 7 & 0 & 0 & 0 & 0 & 10 & 0 & 0 & 0 & 0 & 9 & 0 \\
\hline - Q4 & 0 & 0 & 0 & 7 & 0 & 0 & 0 & 0 & 16 & 0 & 0 & 0 & 0 & 10 & 0 \\
\hline - Q5 & 0 & 0 & 0 & 6 & 0 & 0 & 0 & 0 & 4 & 0 & 0 & 0 & 0 & 6 & 0 \\
\hline \multirow[t]{2}{*}{ - All } & 0 & 0 & 0 & 7 & 0 & 0 & 0 & 0 & 9 & 0 & 0 & 0 & 0 & 8 & 0 \\
\hline & \multicolumn{5}{|c|}{ Urban } & \multicolumn{5}{|c|}{ Rural } & \multicolumn{5}{|l|}{ Both } \\
\hline $\begin{array}{l}\text { Processed } \\
\text { foods }\end{array}$ & P25 & P50 & P75 & P99 & IQR & P25 & P50 & P75 & P99 & IQR & P25 & P50 & P75 & P99 & IQR \\
\hline \multicolumn{16}{|l|}{$\begin{array}{l}\text { A. } \\
\text { Processed } \\
\text { soups, } \\
\text { sauces \& } \\
\text { flavor } \\
\text { enhancers }\end{array}$} \\
\hline - Q1 & 499 & 1118 & 2122 & 8113 & 1623 & 740 & 1446 & 2483 & 9307 & 1743 & 691 & 1413 & 2459 & 8776 & 1767 \\
\hline - Q2 & 354 & 1082 & 1988 & 7526 & 1634 & 718 & 1474 & 2689 & 7452 & 1970 & 555 & 1354 & 2484 & 7452 & 1929 \\
\hline - Q3 & 333 & 1137 & 2174 & 7035 & 1841 & 833 & 1498 & 2547 & 8174 & 1715 & 510 & 1331 & 2372 & 8000 & 1862 \\
\hline - Q4 & 569 & 1375 & 2574 & 10021 & 2004 & 926 & 1679 & 2775 & 7908 & 1849 & 666 & 1454 & 2707 & 9693 & 2041 \\
\hline - Q5 & 705 & 1537 & 2943 & 8020 & 2238 & 916 & 1812 & 3114 & 10778 & 2198 & 713 & 1630 & 2959 & 8720 & 2246 \\
\hline - All & 508 & 1309 & 2496 & 8301 & 1988 & 770 & 1524 & 2635 & 8600 & 1866 & 629 & 1416 & 2556 & 8315 & 1926 \\
\hline \multicolumn{16}{|l|}{$\begin{array}{l}\text { B. } \\
\text { Processed } \\
\text { fish, meat } \\
\text { \& poultry } \\
\text { products }\end{array}$} \\
\hline - Q1 & 0 & 84 & 209 & 1370 & 209 & 0 & 57 & 281 & 1762 & 281 & 0 & 61 & 268 & 1641 & 268 \\
\hline - Q2 & 0 & 95 & 320 & 1501 & 320 & 0 & 128 & 341 & 1596 & 341 & 0 & 113 & 332 & 1596 & 332 \\
\hline - Q3 & 0 & 131 & 362 & 1562 & 362 & 0 & 140 & 353 & 1775 & 353 & 0 & 132 & 360 & 1721 & 360 \\
\hline - Q4 & 0 & 139 & 424 & 2474 & 424 & 0 & 128 & 429 & 2408 & 429 & 0 & 135 & 429 & 2474 & 429 \\
\hline - Q5 & 0 & 152 & 456 & 1957 & 456 & 0 & 143 & 349 & 1553 & 349 & 0 & 150 & 431 & 1888 & 431 \\
\hline - All & 0 & 131 & 392 & 1900 & 392 & 0 & 110 & 330 & 1762 & 330 & 0 & 120 & 358 & 1829 & 358 \\
\hline \multicolumn{16}{|l|}{$\begin{array}{l}\text { C. Baked } \\
\text { products }\end{array}$} \\
\hline - Q1 & 0 & 0 & 55 & 289 & 55 & 0 & 0 & 10 & 353 & 10 & 0 & 0 & 14 & 353 & 14 \\
\hline - Q2 & 0 & 25 & 145 & 695 & 145 & 0 & 0 & 49 & 396 & 49 & 0 & 0 & 86 & 531 & 86 \\
\hline - Q3 & 0 & 67 & 187 & 655 & 187 & 0 & 8 & 91 & 748 & 91 & 0 & 36 & 144 & 679 & 144 \\
\hline - Q4 & 0 & 86 & 240 & 792 & 240 & 0 & 32 & 142 & 550 & 142 & 0 & 63 & 207 & 771 & 207 \\
\hline - Q5 & 30 & 142 & 317 & 920 & 287 & 0 & 87 & 275 & 1088 & 275 & 23 & 131 & 305 & 934 & 282 \\
\hline - All & 0 & 77 & 228 & 771 & 228 & 0 & 0 & 72 & 582 & 72 & 0 & 25 & 150 & 720 & 150 \\
\hline
\end{tabular}




\begin{tabular}{|c|c|c|c|c|c|c|c|c|c|c|c|c|c|c|c|}
\hline \multirow{3}{*}{\begin{tabular}{|l} 
\\
$\begin{array}{l}\text { D. Instan } \\
\text { noodles }\end{array}$
\end{tabular}} & \multicolumn{15}{|c|}{ Per capita Na intake (mg/day) } \\
\hline & \multicolumn{5}{|c|}{ Urban } & \multicolumn{5}{|c|}{ Rural } & \multicolumn{5}{|c|}{ Both } \\
\hline & & & & & & & & & & & & & & & \\
\hline - Q1 & 0 & 0 & 0 & 1076 & 0 & 0 & 0 & 0 & 1050 & 0 & 0 & 0 & 0 & 1064 & 0 \\
\hline - Q2 & 0 & 0 & 0 & 1067 & 0 & 0 & 0 & 11 & 1044 & 11 & 0 & 0 & 0 & 1067 & 0 \\
\hline - Q3 & 0 & 0 & 0 & 1163 & 0 & 0 & 0 & 0 & 960 & 0 & 0 & 0 & 0 & 1032 & 0 \\
\hline - Q4 & 0 & 0 & 0 & 922 & 0 & 0 & 0 & 0 & 800 & 0 & 0 & 0 & 0 & 907 & 0 \\
\hline - Q5 & 0 & 0 & 0 & 990 & 0 & 0 & 0 & 0 & 1110 & 0 & 0 & 0 & 0 & 1000 & 0 \\
\hline - All & 0 & 0 & 0 & 1050 & 0 & 0 & 0 & 0 & 1009 & 0 & 0 & 0 & 0 & 1032 & 0 \\
\hline \multicolumn{16}{|c|}{$\begin{array}{l}\text { E. Other } \\
\text { noodles \& } \\
\text { pasta }\end{array}$} \\
\hline - Q1 & 0 & 0 & 0 & 180 & 0 & 0 & 0 & 0 & 310 & 0 & 0 & 0 & 0 & 259 & 0 \\
\hline - Q2 & 0 & 0 & 0 & 296 & 0 & 0 & 0 & 0 & 360 & 0 & 0 & 0 & 0 & 360 & 0 \\
\hline - Q3 & 0 & 0 & 1 & 445 & 1 & 0 & 0 & 0 & 388 & 0 & 0 & 0 & 1 & 445 & 1 \\
\hline - Q4 & 0 & 0 & 1 & 349 & 1 & 0 & 0 & 0 & 502 & 0 & 0 & 0 & 1 & 423 & 1 \\
\hline - Q5 & 0 & 0 & 2 & 604 & 2 & 0 & 0 & 1 & 745 & 1 & 0 & 0 & 1 & 604 & 1 \\
\hline - All & 0 & 0 & 1 & 482 & 1 & 0 & 0 & 0 & 423 & 0 & 0 & 0 & 0 & 450 & 0 \\
\hline \multicolumn{16}{|c|}{$\begin{array}{l}\text { F. Rice, } \\
\text { cereal, } \\
\text { starch } \\
\text { products }\end{array}$} \\
\hline - Q1 & 0 & 0 & 0 & 140 & 0 & 0 & 0 & 0 & 143 & 0 & 0 & 0 & 0 & 142 & 0 \\
\hline - Q2 & 0 & 0 & 0 & 221 & 0 & 0 & 0 & 0 & 213 & 0 & 0 & 0 & 0 & 221 & 0 \\
\hline - Q3 & 0 & 0 & 1 & 221 & 1 & 0 & 0 & 0 & 156 & 0 & 0 & 0 & 0 & 178 & 0 \\
\hline - Q4 & 0 & 0 & 4 & 289 & 4 & 0 & 0 & 1 & 238 & 1 & 0 & 0 & 3 & 238 & 3 \\
\hline - Q5 & 0 & 0 & 20 & 228 & 20 & 0 & 0 & 17 & 461 & 17 & 0 & 0 & 19 & 276 & 19 \\
\hline - All & 0 & 0 & 6 & 235 & 6 & 0 & 0 & 0 & 209 & 0 & 0 & 0 & 1 & 221 & 1 \\
\hline \multicolumn{16}{|c|}{$\begin{array}{l}\text { G. Non- } \\
\text { alcoholic } \\
\text { beverages }\end{array}$} \\
\hline - Q1 & 0 & 0 & 4 & 44 & 4 & 0 & 0 & 3 & 67 & 3 & 0 & 0 & 3 & 67 & 3 \\
\hline - Q2 & 0 & 0 & 11 & 81 & 11 & 0 & 0 & 7 & 89 & 7 & 0 & 0 & 9 & 82 & 9 \\
\hline - Q3 & 0 & 2 & 16 & 104 & 16 & 0 & 1 & 13 & 71 & 13 & 0 & 1 & 14 & 84 & 14 \\
\hline - Q4 & 0 & 4 & 20 & 119 & 20 & 0 & 3 & 23 & 106 & 23 & 0 & 3 & 21 & 106 & 21 \\
\hline - Q5 & 0 & 10 & 29 & 152 & 28 & 0 & 8 & 22 & 232 & 22 & 0 & 9 & 27 & 159 & 27 \\
\hline - All & 0 & 3 & 19 & 115 & 19 & 0 & 0 & 10 & 91 & 10 & 0 & 1 & 15 & 105 & 15 \\
\hline \multicolumn{16}{|c|}{$\begin{array}{l}\text { H. Milk } \\
\text { formula \& } \\
\text { milk } \\
\text { products }\end{array}$} \\
\hline - Q1 & 0 & 0 & 0 & 5 & 0 & 0 & 0 & 0 & 9 & 0 & 0 & 0 & 0 & 9 & 0 \\
\hline - Q2 & 0 & 0 & 0 & 99 & 0 & 0 & 0 & 0 & 40 & 0 & 0 & 0 & 0 & 55 & 0 \\
\hline - Q3 & 0 & 0 & 0 & 142 & 0 & 0 & 0 & 0 & 67 & 0 & 0 & 0 & 0 & 120 & 0 \\
\hline
\end{tabular}




\begin{tabular}{|c|c|c|c|c|c|c|c|c|c|c|c|c|c|c|c|}
\hline \multirow{3}{*}{ - Q4 } & \multicolumn{15}{|c|}{ Per capita $\mathrm{Na}$ intake (mg/day) } \\
\hline & \multicolumn{5}{|c|}{ Urban } & \multicolumn{5}{|c|}{ Rural } & \multicolumn{5}{|c|}{ Both } \\
\hline & 0 & 0 & 0 & 246 & 0 & 0 & 0 & 0 & 262 & 0 & 0 & 0 & 0 & 246 & 0 \\
\hline - Q5 & 0 & 0 & 31 & 362 & 31 & 0 & 0 & 12 & 297 & 12 & 0 & 0 & 26 & 362 & 26 \\
\hline - All & 0 & 0 & 0 & 285 & 0 & 0 & 0 & 0 & 91 & 0 & 0 & 0 & 0 & 215 & 0 \\
\hline \multicolumn{16}{|c|}{$\begin{array}{l}\text { I. Fats, oils, } \\
\text { \& products }\end{array}$} \\
\hline - Q1 & 0 & 0 & 1 & 20 & 1 & 0 & 0 & 0 & 24 & 0 & 0 & 0 & 1 & 23 & 1 \\
\hline - Q2 & 0 & 0 & 2 & 41 & 2 & 0 & 0 & 1 & 34 & 1 & 0 & 0 & 2 & 41 & 2 \\
\hline - Q3 & 0 & 0 & 3 & 155 & 3 & 0 & 0 & 2 & 95 & 2 & 0 & 0 & 3 & 98 & 3 \\
\hline - Q4 & 0 & 1 & 5 & 89 & 5 & 0 & 0 & 3 & 196 & 3 & 0 & 0 & 4 & 117 & 4 \\
\hline - Q5 & 0 & 2 & 6 & 176 & 6 & 0 & 0 & 5 & 208 & 4 & 0 & 1 & 5 & 176 & 5 \\
\hline - All & 0 & 0 & 3 & 131 & 3 & 0 & 0 & 2 & 82 & 2 & 0 & 0 & 3 & 106 & 3 \\
\hline \multicolumn{16}{|c|}{$\begin{array}{l}\text { J. Beans, } \\
\text { nuts, seed } \\
\text { products }\end{array}$} \\
\hline - Q1 & 0 & 0 & 0 & 5 & 0 & 0 & 0 & 0 & 1 & 0 & 0 & 0 & 0 & 3 & 0 \\
\hline - Q2 & 0 & 0 & 0 & 11 & 0 & 0 & 0 & 0 & 9 & 0 & 0 & 0 & 0 & 11 & 0 \\
\hline - Q3 & 0 & 0 & 0 & 24 & 0 & 0 & 0 & 0 & 3 & 0 & 0 & 0 & 0 & 21 & 0 \\
\hline - Q4 & 0 & 0 & 0 & 28 & 0 & 0 & 0 & 0 & 13 & 0 & 0 & 0 & 0 & 24 & 0 \\
\hline - Q5 & 0 & 0 & 0 & 28 & 0 & 0 & 0 & 0 & 45 & 0 & 0 & 0 & 0 & 28 & 0 \\
\hline - All & 0 & 0 & 0 & 24 & 0 & 0 & 0 & 0 & 8 & 0 & 0 & 0 & 0 & 14 & 0 \\
\hline \multicolumn{16}{|c|}{$\begin{array}{l}\text { K. Sugars } \\
\& \text { sweets }\end{array}$} \\
\hline - Q1 & 0 & 0 & 2 & 40 & 2 & 0 & 0 & 2 & 21 & 2 & 0 & 0 & 2 & 21 & 2 \\
\hline - Q2 & 0 & 0 & 1 & 12 & 1 & 0 & 1 & 3 & 26 & 3 & 0 & 0 & 2 & 19 & 2 \\
\hline - Q3 & 0 & 0 & 1 & 19 & 1 & 0 & 0 & 2 & 23 & 2 & 0 & 0 & 2 & 20 & 2 \\
\hline - Q4 & 0 & 0 & 1 & 39 & 1 & 0 & 0 & 2 & 33 & 2 & 0 & 0 & 2 & 33 & 2 \\
\hline - Q5 & 0 & 0 & 2 & 43 & 2 & 0 & 0 & 2 & 57 & 2 & 0 & 0 & 2 & 43 & 2 \\
\hline - All & 0 & 0 & 1 & 29 & 1 & 0 & 0 & 2 & 23 & 2 & 0 & 0 & 2 & 26 & 2 \\
\hline \multicolumn{16}{|c|}{$\begin{array}{l}\text { L. } \\
\text { Vegetable } \\
\text { \& fruit } \\
\text { products }\end{array}$} \\
\hline - Q1 & 0 & 0 & 0 & 134 & 0 & 0 & 0 & 0 & 0 & 0 & 0 & 0 & 0 & 0 & 0 \\
\hline - Q2 & 0 & 0 & 0 & 1 & 0 & 0 & 0 & 0 & 0 & 0 & 0 & 0 & 0 & 0 & 0 \\
\hline - Q3 & 0 & 0 & 0 & 11 & 0 & 0 & 0 & 0 & 5 & 0 & 0 & 0 & 0 & 6 & 0 \\
\hline - Q4 & 0 & 0 & 0 & 16 & 0 & 0 & 0 & 0 & 11 & 0 & 0 & 0 & 0 & 16 & 0 \\
\hline - Q5 & 0 & 0 & 0 & 50 & 0 & 0 & 0 & 0 & 5 & 0 & 0 & 0 & 0 & 49 & 0 \\
\hline - All & 0 & 0 & 0 & 30 & 0 & 0 & 0 & 0 & 4 & 0 & 0 & 0 & 0 & 15 & 0 \\
\hline \multicolumn{16}{|c|}{$\begin{array}{l}\text { M. } \\
\text { Alcoholic } \\
\text { beverages }\end{array}$} \\
\hline - Q1 & 0 & 0 & 0 & 0 & 0 & 0 & 0 & 0 & 3 & 0 & 0 & 0 & 0 & 1 & 0 \\
\hline
\end{tabular}




\begin{tabular}{|c|c|c|c|c|c|c|c|c|c|c|c|c|c|c|c|}
\hline \multirow[b]{3}{*}{ - Q2 } & \multicolumn{15}{|c|}{ Per capita Na intake (mg/day) } \\
\hline & \multicolumn{5}{|c|}{ Urban } & \multicolumn{5}{|c|}{ Rural } & \multicolumn{5}{|c|}{ Both } \\
\hline & 0 & 0 & 0 & 4 & 0 & 0 & 0 & 0 & 25 & 0 & 0 & 0 & 0 & 15 & 0 \\
\hline - Q3 & 0 & 0 & 0 & 2 & 0 & 0 & 0 & 0 & 2 & 0 & 0 & 0 & 0 & 2 & 0 \\
\hline - Q4 & 0 & 0 & 0 & 1 & 0 & 0 & 0 & 0 & 20 & 0 & 0 & 0 & 0 & 4 & 0 \\
\hline - Q5 & 0 & 0 & 0 & 5 & 0 & 0 & 0 & 0 & 109 & 0 & 0 & 0 & 0 & 5 & 0 \\
\hline - All & 0 & 0 & 0 & 3 & 0 & 0 & 0 & 0 & 6 & 0 & 0 & 0 & 0 & 4 & 0 \\
\hline
\end{tabular}

\section{b. Percentage contribution of processed and minimally processed foods to per capita sodium intake}

Table 2 shows the percentage contribution of processed and minimally processed foods to per capita sodium intake of urban and rural households across income quintiles.

Table 2. Percentage contribution of processed and minimally processed foods to per capita sodium intake by income quintile in urban and rural households. Philippines 2008. 
Percentage contribution to mean per capita Na intake (\%)

Urban households Rural households

$\begin{array}{lllllllllllll}\text { Q1 } & \text { Q2 } & \text { Q3 } & \text { Q4 } & \text { Q5 } & \text { All } & \text { Q1 } & \text { Q2 } & \text { Q3 } & \text { Q4 } & \text { Q5 } & \text { All }\end{array}$

1. Processed foods

\begin{tabular}{|lccccccccccccc}
$\begin{array}{l}\text { Processed soup, sauces \& } \\
\text { flavor enhancers }\end{array}$ & 57.96 & 55.86 & 58.14 & 73.20 & 76.56 & 67.36 & 71.62 & 72.7 & 74.93 & 79.39 & 97.41 & 75.83 \\
\hline $\begin{array}{l}\text { Processed fish, meat \& poultry } \\
\text { products }\end{array}$ & 7.37 & 8.77 & 9.96 & 11.53 & 12.34 & 10.75 & 7.41 & 9.10 & 9.70 & 11.29 & 9.90 & 9.08 \\
\hline Baked products & 1.55 & 3.85 & 4.82 & 5.85 & 7.83 & 5.66 & 1.01 & 1.71 & 2.80 & 3.75 & 6.48 & 2.40 \\
\hline Instant noodles & 3.33 & 3.93 & 3.87 & 3.21 & 3.04 & 3.45 & 3.94 & 4.37 & 3.82 & 3.52 & 3.09 & 3.89 \\
\hline Other noodles \& pasta & 0.46 & 0.68 & 1.02 & 0.93 & 1.07 & 0.92 & 0.47 & 0.51 & 0.70 & 0.99 & 1.37 & 0.68 \\
\hline Rice, cereal, starch products & 0.38 & 0.50 & 0.56 & 0.80 & 0.83 & 0.68 & 0.26 & 0.52 & 0.46 & 0.54 & 0.96 & 0.46 \\
\hline Milk formula \& milk products & 0.00 & 0.17 & 0.28 & 0.42 & 1.26 & 0.58 & 0.01 & 0.06 & 0.14 & 0.41 & 0.76 & 0.17 \\
\hline Non-alcoholic beverages & 0.21 & 0.31 & 0.44 & 0.55 & 0.78 & 0.54 & 0.23 & 0.31 & 0.35 & 0.56 & 0.83 & 0.37 \\
\hline Fats, oils \& products & 0.05 & 0.13 & 0.18 & 0.31 & 0.46 & 0.28 & 0.07 & 0.10 & 0.17 & 0.28 & 0.28 & 0.15 \\
\hline Sugars \& sweets & 0.08 & 0.05 & 0.05 & 0.09 & 0.11 & 0.08 & 0.07 & 0.09 & 0.07 & 0.10 & 0.12 & 0.08 \\
\hline Beans, nuts, seed products & 0.01 & 0.01 & 0.02 & 0.07 & 0.12 & 0.06 & 0.01 & 0.27 & 0.12 & 0.02 & 0.14 & 0.10 \\
\hline Veg \& fruit products & 0.10 & 0.08 & 0.03 & 0.03 & 0.08 & 0.06 & 0.01 & 0.04 & 0.04 & 0.03 & 0.02 & 0.03 \\
\hline Alcoholic beverages & 0.00 & 0.04 & 0.00 & 0.00 & 0.01 & 0.01 & 0.03 & 0.04 & 0.00 & 0.02 & 0.08 & 0.03 \\
\hline
\end{tabular}

2. Minimally processed foods

\begin{tabular}{lllllllllllll} 
Fish, meat, poultry & 2.17 & 3.52 & 4.30 & 4.55 & 5.93 & 4.61 & 2.14 & 3.08 & 4.09 & 5.51 & 6.68 & 3.63 \\
\hline Rice, cereals, starches & 3.12 & 3.16 & 3.19 & 3.03 & 2.78 & 3.01 & 3.29 & 3.41 & 3.30 & 3.39 & 3.14 & 3.32 \\
\hline Veg \& fruits & 0.42 & 0.45 & 0.45 & 0.51 & 0.57 & 0.50 & 0.57 & 0.55 & 0.52 & 0.62 & 0.70 & 0.57 \\
\hline Milk & 0.18 & 0.26 & 0.36 & 0.40 & 0.50 & 0.39 & 0.12 & 0.26 & 0.26 & 0.35 & 0.35 & 0.23 \\
\hline Beans, nuts, seeds & 0.01 & 0.01 & 0.01 & 0.02 & 0.01 & 0.01 & 0.01 & 0.02 & 0.02 & 0.03 & 0.01 & 0.02
\end{tabular}

Processed foods. In both urban and rural households, Processed Soup, Sauces and Flavor Enhancers contributed the greatest amount ( $>50 \%)$ to sodium intake, followed by Fish, Meat and Poultry Products. Rural households consumed more Processed Soup, Sauces and Flavor enhancers across all income quintiles than urban households. Baked Products and Instant Noodles were the next highest contributors. Urban households consumed more Baked Products while rural households consumed more Instant Noodles.

Minimally processed foods. Among the highest income quintiles, minimally processed food categories that contributed the most sodium were Fish, Meat and Poultry followed by Rice, Cereals and Starches. In lower income quintiles, (Q1 in urban and rural areas, and Q2 in rural areas), Rice, Cereals and Starches contributed the most sodium followed by Fish, Meat and Poultry. In both urban and rural locations, Vegetables and Fruits contributed minimal amounts (<1\%) of sodium. Foods that contributed the least amount to sodium intake were Milk followed by Beans, Nuts and Seeds.

\section{c. Foods that contribute significantly to the variance in per capita sodium intake}

Table 3 shows the results of multiple regression analysis. A total of 15 foods ( 13 foods belonging to the processed food group, and 2 foods belonging to the minimally processed group) explained the variance in per capita sodium intake. Minimally processed foods that contributed significantly to sodium were cooked white rice and ready-to-eat prepared foods (fish, meat, poultry, organ meats). All other foods with significant contributions belonged to the processed food group. Among all minimally processed and processed foods, cooked white rice contributed the greatest amount of sodium (i.e., consumption of one gram of rice increased per capita sodium intake by 0.79 mg) followed by 
instant noodles (i.e., consumption of one gram instant noodles increased per capita sodium intake by $0.02 \mathrm{mg}$ ). This was followed by traditional condiments (fermented fish/seafood sauce), table salt, and processed meat, fish, poultry products.

Table 3

Food groups/subgroups and foods within each subgroup that contribute significantly to the variance in per capita sodium intake of Filipinos

\begin{tabular}{|c|c|c|c|}
\hline $\mathrm{R}^{2} /$ Adjusted $\mathrm{R}^{2}=99.39 \%$ & Coefficient (b) & Linearized robust S.E. & p-value \\
\hline \multicolumn{4}{|l|}{ A. Processed foods } \\
\hline 1. Instant noodles & 0.019 & 0.001 & 0.000 \\
\hline \multicolumn{4}{|l|}{ 2. Processed soup, sauces, flavor enhancers } \\
\hline - Fermented fish/seafood sauce & 0.011 & 0.003 & 0.001 \\
\hline - Table salt & 0.011 & 0.003 & 0.000 \\
\hline \multicolumn{4}{|l|}{ 3. Processed fish, meat, poultry products } \\
\hline - Dried and smoked fish \& seafood & 0.010 & 0.003 & 0.004 \\
\hline - Canned \& processed meat, fish, seafood & 0.007 & 0.003 & 0.023 \\
\hline - Eggs salted & 0.004 & 0.002 & 0.031 \\
\hline 4. Alcoholic beverages & 0.009 & 0.004 & 0.034 \\
\hline \multicolumn{4}{|l|}{ 5. Baked products } \\
\hline - White bread \& pandesal & 0.008 & 0.015 & 0.000 \\
\hline \multicolumn{4}{|l|}{ 6. Other noodles \& pasta } \\
\hline - Noodles (wheat and egg) & 0.006 & 0.003 & 0.016 \\
\hline \multicolumn{4}{|l|}{ 7. Rice, cereal \& starch products } \\
\hline - Crispy cereal chips \& extruded snacks & 0.005 & 0.001 & 0.000 \\
\hline \multicolumn{4}{|l|}{ 8. Fats, oils \& products } \\
\hline - Butter \& margarine & 0.005 & 0.002 & 0.010 \\
\hline \multicolumn{4}{|l|}{ 9. Milk products } \\
\hline - Cheese \& fermented dairy products & 0.004 & 0.001 & 0.011 \\
\hline \multicolumn{4}{|l|}{ 10. Non-alcoholic beverages } \\
\hline - Chocolate beverage & 0.002 & 0.001 & 0.034 \\
\hline \multicolumn{4}{|l|}{ B. Minimally processed foods } \\
\hline \multicolumn{4}{|l|}{ 1. Rice, cereals, starches } \\
\hline - Cooked white rice & 0.790 & 0.267 & 0.003 \\
\hline \multicolumn{4}{|l|}{ 2. Fish, meat, poultry } \\
\hline - Prepared dishes (ready-to-eat) & 0.010 & 0.004 & 0.012 \\
\hline
\end{tabular}

\section{Discussion}

The prevalence of hypertension among adult Filipinos aged 20 years and above increased from $16 \%$ in 2003 to $21 \%$ in 2008 [4] to $28 \%$ in 2013 [5], highlighting the need to reduce sodium intake. The present study identified processed foods that can be targeted for reformulation to achieve reduced salt intake. Important sources of sodium were 13 foods in the processed food group and 2 foods in the minimally processed group, which together accounted for $99.4 \%$ of the variance in sodium intake of the entire population. In the processed foods group, the greatest contributors were the following: instant noodles and foods in the following categories: Processed Soup, Sauces \& Flavor Enhancers (traditional fermented fish \& seafood sauces, table salt); Processed Fish, Meat \& Poultry Products (dried/smoked fish \& seafood, canned \& processed meat/fish/seafood, salted eggs); Baked Products (white bread, pan de sal); Other Noodles \& Pasta (wheat and egg noodles); Rice, 
Cereal \& Starch Products (crispy cereal chips and extruded snacks); Fats, Oils \& Products (butter, margarine); Milk Products (cheese); Nonalcoholic Beverages (chocolate-based drinks).

Instant noodles. Estimated per capita consumption of instant noodles in 2008 was $2.86 \mathrm{~kg} / \mathrm{year}$ [6] or approximately $8 \mathrm{~g} / \mathrm{day}$, contributing $158 \mathrm{mg} \mathrm{Na}$ /day. In 2017, instant noodles was the top noodle product consumed in the Philippines (consumed by 70.12\% of households) [7]. Households consumed an average of $0.05 \mathrm{~kg}$ instant noodles per week or $2.69 \mathrm{~kg}$ a year. Rural households consumed greater amounts at $2.78 \mathrm{~kg}$ per year. During the same period, $27.6 \%$ of households reported substituting instant noodles for rice. The most frequent reason for substitution (reported by $18.43 \%$ of respondents) was that it is more affordable than rice [7]. Instant noodles contain $\approx 1975 \mathrm{mg} \mathrm{Na/100} \mathrm{g}$ [8]. Wheat and egg noodles (commonly called pancit canton) contain $\approx 1006 \mathrm{mg} \mathrm{Na} / 100 \mathrm{~g}$ [9].

Processed soup, sauces and flavor enhancers. Within this category, table salt and traditional fermented fish/seafood sauces were the significant contributors to sodium intake. In 2008, coarse salt was the most commonly consumed condiment in the Philippines, with $64.9 \%$ of households consuming an average of 3 grams salt per day [10], equivalent to $1200 \mathrm{mg} \mathrm{Na}$. Philippine shrimp paste contains $13-14 \mathrm{~g}$ Na/100 $\mathrm{g}$ [11]. The percentage of households consuming these traditional fermented foods in 2008 [12] was: bagoong isda (fermented anchovy), ginamos (fermented shrimp) - 10.1\%; patis (fish sauce) - 6.1\%; bagoong alamang (shrimp paste) - $4.7 \%$. In a study among 1789 women, Lee found that salty condiments added during cooking or at the table accounted for $76.3 \%$ of sodium intake [13]. The most significant source of sodium was table salt, contributing $53.3 \%$ for women who consumed $<4600 \mathrm{mg} /$ day of sodium and $66.5 \%$ for women who consumed higher amounts of sodium.

\section{Pros and cons of indigenous fermented sauces}

Traditional fermented salted products, while contributing significantly to sodium intake of Filipinos, are an important part of the food culture in the Philippines. Commonly used indigenous sauces are fermented fish and seafood sauces (patis or fish sauce, bagoong or fish/shrimp paste), soy sauce. These products are generally produced with high levels of salt, up to $25 \%$ for fish sauces and 11 to $25 \%$ for soy sauce [14] [15]. High levels of salt and low pH are important to suppress the growth of pathogenic microorganisms and enable bacterial degradation of proteins, carbohydrates, and nucleic acids. In spite of their high sodium content, these fermented sauces were shown to have functional effects. Japanese style fermented soy sauce (shoyu) showed antiallergic, antimicrobial, antihypertensive, and anticarcinogenic effects [16] [17]. Fermented foods contain live microorganisms and therefore comprise a good source of probiotics. Lactic acid bacteria were found in

fermented fish (ranging from 3.48 to $5.43 \mathrm{log} \mathrm{cfu} / \mathrm{g}$ ) while aerobic bacteria were found in fish sauce (ranging from 4.92 to $5.53 \mathrm{log}$ cfu/g [18]). Fermentation-derived microorganisms have the potential to influence gut microbiota diversity, structure, and function and increase the amount of nutrients such as vitamins and other bioactive molecules produced from microbial metabolism that are not present in the original food [18]. These bacteria may also secrete anti-microbial agents, degrade anti-nutritive compounds, produce short-chain fatty acids from indigestible carbohydrates, and contribute to immune homeostasis [18] [19] [20]. A study on the composition of shrimp pastes produced in some parts of the Philippines showed these foods were good sources of omega-3 fatty acids, iron, zinc, and calcium [11]. Due to their extensive use, fortification of condiments and seasonings is also seen as a cost-effective intervention to address micronutrient deficiencies in Southeast Asia [21] [22]. Studies in young children and adult women suggested that fortification of sauces (fish sauce, soy sauce) can effectively address iron and iodine deficiencies [23] [24].

Processed fish, meat, poultry products. Foods that contributed significantly to sodium intake were dried/smoked fish and seafood, canned/processed meat, fish \& seafood, and salted eggs. In 2008, consumption of fish and fish products was 110 grams per capita. Canned sardines (containing approximately $521 \mathrm{mg} \mathrm{Na} / 100 \mathrm{~g}$ ) [8] was consumed by $15.3 \%$ of households with mean consumption of 8 grams per capita per day [10]. Dried and smoked fish was consumed by $20.5 \%$ of households [12]. Dried fish contains $\approx 7000 \mathrm{mg} \mathrm{Na}$ per $100 \mathrm{~g}$ [25]. Filipinos aged $60+$ years ate the most fish and fish products ( $15.6 \%$ of total food consumption), followed by those aged 20 to 59 years ( $14.7 \%$ of total consumption) [12].

Consumption of meat and meat products in 2008 was 83 grams per capita. The Family Income and Expenditure Survey (FIES) showed that household food expenditures on meats increased by 4 to 5 percentage points from 1965 to 2000 . The biggest growth in expenditure was for processed meats, increasing by $2.7 \%$ during the same period [26]. In 2003, processed meat products (hotdogs, meatloaf, sausages) represented nearly $30 \%$ of per capita meat intake [27].

\section{Limitations of the study}

The study examined only 2008 national food consumption data. Data from multiple successive surveys should be examined since the market for processed foods is dynamic, with products constantly being introduced, reformulated, or taken out. In spite of this, the present study is the currently the only one that identifies sodium-contributing foods for development of population sodium reduction initiatives. The consumption of processed foods among Filipinos has increased over time. For instance, the demand for instant noodles in the Philippines increased from 3400 million servings in 2016 to 4470 million servings in 2020 [28]. For processed meat, the average volume per person is expected to amount

Page $10 / 16$ 
to $3.9 \mathrm{~kg}$ in 2021 and the market is expected to grow annually by $1.89 \%$ from 2021 to 2025 [29]. During this pandemic, sodium intake is expected to increase further. Food relief packs distributed nationwide by the Department of Social Welfare and Development contain rice, corned beef, sardines, and chocolate energy drink or coffee [30]. Corned beef, sardines, and chocolate beverage are among the foods identified in this study which significantly contribute to the variance in sodium intake of Filipinos.

\section{Conclusions}

Indicator foods that can be targeted for reformulation and monitored over time to reduce population sodium intake among Filipinos are instant noodles, traditional fermented condiments and sauces, and processed meat, fish, and poultry products. Other processed foods with significant contributions to the variance in sodium intake and whose consumption can be reduced via consumer education and reformulation (e.g., "stealth" reductions) are table salt, alcoholic beverages, white bread and pan de sal (a traditional bread), crispy cereal chips and extruded snacks, butter and margarine, cheese, and chocolate based beverages.

\section{Methods}

Aim, design and setting. The study identified processed foods that can be targeted for reformulation and whose sodium content can be monitored over time to achieve reduced sodium intake in the Philippines. This cross-sectional study examined per capita food consumption obtained from one-day household food weighing data of 4880 households participating in the 2008 National Nutrition Survey.

Sampling method. The 2008 National Nutrition Survey used a stratified multi-stage sampling design. In the first stage, primary sampling units were selected from 17 regions and 79 provinces throughout the country. In the second stage, enumeration areas were identified from primary sampling units. Finally specific households from each enumeration area were selected, comprising a total of 4880 households (median 5 members per household) nationwide.

Characteristics of the sample. The sample comprised $43 \%$ urban and $57 \%$ rural households with more households belonging to lower income groups, reflecting the country's socioeconomic classification as a low middle income country. Table 4 shows the distribution of households by location of residence and wealth quintile.

Table 4

Distribution of sample households. Philippines 2008

\begin{tabular}{|lllllll|}
\hline & Urban & \multicolumn{3}{c|}{ Rural } & Both \\
\hline Wealth quintile & No. & $\%$ & No. & $\%$ & No. & $\%$ \\
Q0 (unidentified) & 5 & 0 & 7 & 0 & 12 & 0 \\
\hline Q1 (lowest) & 167 & 3 & 945 & 19 & 1112 & 23 \\
\hline Q2 & 351 & 7 & 685 & 14 & 1036 & 21 \\
\hline Q3 & 466 & 10 & 511 & 10 & 977 & 20 \\
\hline Q4 & 540 & 11 & 403 & 8 & 943 & 19 \\
\hline Q5 (highest) & 592 & 12 & 208 & 4 & 800 & 16 \\
\hline All & 2121 & 43 & 2759 & 57 & 4880 & 100 \\
\hline Median number of household members $=5$ & & \\
\hline
\end{tabular}

Data collection. One-day household weighing of food items from breakfast through supper, including snacks was conducted. Digital dietetic scales were calibrated using a one-kg standard weight. On the day of weighing, all items were weighed before cooking or serving including: raw as purchased foods to be cooked for each meal and snacks, food served and eaten raw, cooked and processed foodstuff served directly on the dining table. Leftover foods were weighed and, together with the weights of plate wastes and foods given out, were deducted from the sum of weighed food to obtain the actual amount of food consumed by the household [31]. A food inventory was also conducted. Nonperishable food items that might be used anytime of the day such as coffee, sugar, salt, cooking oil, and other condiments were weighed at the beginning and end of the food weighing day. Foods eaten by household members who ate outside their homes were recalled and recorded to complete the household's food record. Sample weighing of similar food items eaten out was performed for validation purposes [31]. 
Data analysis. Prior to statistical analysis, the following steps were taken: 1) Creation of a food composition database for sodium; 2) Grouping of all foods consumed into 2 categories: Minimally Processed Foods and Processed Foods/Food Products.

Development of a food composition database for sodium. The Philippine food composition table does not provide nutrient values for sodium. Hence, the sodium content of all foods consumed was estimated from values derived from different food composition tables, using the process described by INFOODS. The INFOODS guidelines for food matching [32] guided the selection of appropriate foods from which to borrow sodium values, in the most appropriate source of compositional data. Values for sodium consumption were then computed by multiplying each food's sodium content by the amount consumed by the entire household.

Grouping of foods into minimally processed and processed food categories. Almost all foods consumed in the Filipino diet are processed or cooked to a certain extent prior to ingestion. FAO [33] recommended that the level of food processing should be taken into account when examining food consumption data, so as to inform the development and implementation of food-based guidelines and approaches to the prevention of chronic diseases. The NOVA food classification system [33] [34] developed by researchers in Brazil, classifies foods according to the nature, degree, and purpose of processing. The present study used a modified version of the NOVA classification wherein foods were classified into two main groups and each group was further classified into subgroups:

1) Minimally Processed Foods (subgroups comprised cooked/prepared whole foods, e.g., boiled rice and tubers, whole fish/meat/chicken dishes, milk (fresh liquid and whole milk powder), raw or cooked whole vegetables and fruits), and

2) Processed Foods (subgroups comprised processed and preserved/salted food products, foods made from processed ingredients).

All foods consumed by survey households were listed. Similar foods were grouped into specific subgroups (a total of 18 subgroups or categories were created for 1306 individual food items). Each food category was classified as belonging to either the minimally processed or processed groups (shown in Table 5). This classification was done to allow the development of recommendations for sodium reduction that correspond to dietary patterns of the entire population.

Table 5. Minimally processed and processed foods consumed by the population, Philippines 2008 


\begin{tabular}{|c|c|}
\hline Main food groups \& categories & Foods in each category \\
\hline \multicolumn{2}{|l|}{ A. Minimally processed foods } \\
\hline \multirow[t]{4}{*}{ 1. Fish, meat, poultry } & Fresh meat, poultry, organ meat \\
\hline & Fresh fish \& seafood \\
\hline & Prepared dishes ready-to-eat \\
\hline & Unsalted fresh eggs \\
\hline \multirow[t]{3}{*}{ 2. Rice, cereals, starches } & Cooked rice \\
\hline & Corn \& other cereals \\
\hline & Starchy roots \& tubers \\
\hline \multirow[t]{3}{*}{ 3. Vegetables \& fruits } & Fresh fruits \& vegetables \\
\hline & Seaweed dried \& fresh \\
\hline & Sundried \& cooked fruits \\
\hline 4. Beans, nuts, seeds & Cooked beans, nuts, seeds dishes \\
\hline \multirow[t]{4}{*}{ 5. Milk } & Liquid milk (fresh, evaporated, recombined); \\
\hline & Milk powder (whole, full cream, filled); \\
\hline & Skimmed milk \\
\hline & Fermented milk \\
\hline \multicolumn{2}{|l|}{ B. Processed foods/food products } \\
\hline \multirow[t]{3}{*}{ 6. Processed fish, meat $\&$ poultry products } & Canned \& processed meat, fish, seafood \\
\hline & Dried \& smoked fish \& seafood \\
\hline & Salted eggs \\
\hline \multirow[t]{4}{*}{ 7. Baked products } & White bread \& pan de sal \\
\hline & Sweet breads \\
\hline & Biscuits, crackers, cookies \\
\hline & Cakes, pies, pastries \\
\hline 8. Instant noodles & Instant noodles \\
\hline \multirow[t]{4}{*}{ 9. Processed soup, sauces, flavor enhancers } & Soup powder \\
\hline & Fermented fish \& seafood sauce \\
\hline & Salt \\
\hline & MSG and MSG-containing cubes \\
\hline \multirow[t]{2}{*}{ 10. Other noodles \& pasta } & Wheat \& egg noodles \\
\hline & rice \& mungbean noodles \\
\hline \multirow[t]{7}{*}{ 11. Rice, cereal, starch products } & Sweetened rice cakes \& snacks \\
\hline & sweet popcorn \\
\hline & crispy cereal chips \& extruded snacks \\
\hline & breakfast cereal \\
\hline & cassava cake $\&$ snacks \\
\hline & infant cereal \\
\hline & starch wrappers \\
\hline
\end{tabular}




\begin{tabular}{|l|l|}
\hline Main food groups \& categories & Foods in each category \\
\hline 12. Non-alcoholic beverages & Coffee/ tea \\
& Chocolate beverage \\
& Sweetened juice \& other sweet drinks \\
& Softdrink \\
\hline 13. Fats, oils, \& products & Cooking oil \& lard \\
& Creamers \& cream \\
& Butter \& margarine \\
& Peanut butter, mayonnaise \& spreads \\
\hline 14. Sugars \& sweets & Sugar (refined, second class, crude) \\
& Candies \& jams \\
\hline 15. Milk formula \& milk products & Milk formula for adults, infants \& children \\
& Ice cream \& dairy products \\
& Cheese \& fermented dairy products \\
& Condensed milk \\
\hline 18. Beans, nuts \& seed products & Beer \& indigenous alcoholic beverages \\
\hline 16. Alcoholic beverages & Canned fruit \& fruit juice \\
\hline Vegetable \& fruit products & Canned vegetables \\
& Preserved fruits \\
\hline & Soyfoods \& beverages \\
& Salted nuts \& seeds \\
\hline
\end{tabular}

\section{Statistical analysis.}

Per capita consumption of sodium from different food subcategories was obtained by summing the total amount of sodium (in milligrams) ingested by the entire household divided by the number of consumption units. Percentiles of sodium intake (P25, P50, P75, P99) from different food subcategories and interquartile range (IQR) were obtained using STATA. The percentage contribution of different food categories to mean per capita intake was calculated using the ratio of means wherein mean sodium intake from a specific category was divided by mean per capita sodium intake.

Multiple regression analysis was used to identify specific foods that contributed to the variance in sodium intake for the entire population. Sodium intake values from specific foods in the different categories shown in Table 5 were transformed logarithmically. Thus the form of the regression model fitted is

\section{$\log$ Sodium $=\beta_{o}+\beta_{1} \log V_{1}+\beta_{2} \log V_{2}+\cdots+\beta_{p} \log V_{p}+\varepsilon$}

where $V_{1}, V_{2}, \ldots, V_{p}$ are the milligram consumption in different foods across food groups, and $\epsilon$ is the error term that represents the variation not due to food consumption, including measurement errors. The significant variables were obtained by backward elimination. Variables in the equation were retained at $5 \%$ level of significance. To account for heteroskedasticity, the linearized robust standard errors were produced. Outliers and influential observations were excluded from the analysis.

\section{Declarations}

\section{Ethics approval and consent to participate}

The study used secondary data hence ethical approval was not required. The Philippines National Nutrition Surveys are approved by the Food and Nutrition Research Institute's Institutional Ethics Review Board. All participants sign a consent form prior to participation. 
Not applicable

\section{Availability of data and materials}

The datasets generated and/or analysed during the current study are not publicly available due to [INTELLECTUAL PROPERTY CLAIMS BY FOOD AND NUTRITION RESEARCH INSTITUTE]. Data are available from Mr. Glen Gironella (email glengironella@gmail.com ) upon request and payment of a fee set by the Institute.

\section{Competing interests}

MVC and GG received funding support from International Life Sciences Institute Southeast Asia Region. MSA and FDLR have no conflict of interest to declare.

\section{Funding}

Publication fees are paid for by International Life Sciences Institute Southeast Asia Region. ILSI SEA is supported by its industry members.

\section{Authors' contributions}

MSA conceptualized the study and wrote the manuscript. FDLR and GG processed and analysed the data. MVC reviewed the final draft of the manuscript. All authors read and approved the final manuscript.

\section{Acknowledgements}

Acknowledgement is given to International Life Sciences Institute Southeast Asia Region (ILSI SEAR) Science Cluster on Food and Nutrients for Public Health Guidance for partial funding support.

\section{References}

1. WHO. Global action plan for the prevention and control of noncommunicable diseases. Geneva: World Health Organization; 2013.

2. WHO. Population sodium reduction strategies. 2021. https://www.who.int/dietphysicalactivity/reducingsalt/en/. Accessed 6 June 2021.

3. Ahuja JKC, Pehrsson PR, Haytowitz DB, Wasswa-Kintu S, Nickle M, Showell B. et.al. Sodium monitoring in commercially processed and restaurant foods. Am J Clin Nutr. 2015. doi:10.3945/ajcn.114.084954.

4. Philippine Council for Health Research and Development. Prevalence of hypertension among Filipinos increasing - PSH. 2012. https://www.pchrd.dost.gov.ph/index.php/news/2806-prevalence-of-hypertension-among-filipinos-increasing-psh. Accessed 6 June 2021.

5. Pino G. DOH, PSH launch program to curb hypertension prevalence. 2019. https://www.pna.gov.ph/articles/1058720. Accessed 6 June 2021.

6. Bureau of Agricultural Statistics. Survey of food demand for agricultural commodities in the Philippines. National and regional levels. Quezon City: Department of Agriculture; 2010.

7. Philippines Statistics Authority. National and regional consumption of selected agricultural commodities in the Philippines. Vol. 1. Quezon City: Philippine Statistics Authority; 2017.

8. Mahidol University. ASEAN food composition database. Electronic version 1. Thailand: ASEANFOODS Regional Centre and INFOODS Regional Database Centre. 2014. http://www.inmu.mahidol.ac.th/aseanfoods/doc/OnlineASEAN_FCD_V1_2014.pdf. Accessed 3 Dec 2016.

9. Open Food Facts. Lucky Me instant pancit canton chili-mansi-Monde Nissin-30 g. https://world.openfoodfacts.org/product/4807770273698/lucky-me-instant-pancit-canton-chili-mansi-monde-nissin. Accessed 22 March 2021.

10. Food and Nutrition Research Institute Philippines. 7th National Nutrition Survey. 2008. Food consumption survey component. Food consumption and nutrient intake of Filipino households. 2008. http://www.fnri.dost.gov.ph/images/sources/food_consumption_households.pdf. Accessed 29 Nov 2018.

11. Pilapil ARB. Characterization of salt-fermented shrimp paste from the Philippines [Master's dissertation for Master of Science in Food Technology]. Belgium: Faculty of Bioscience Engineering, Universiteit Ghent; 2013. https://libstore.ugent.be/fulltxt/RUG01/002/063/539/RUG01-002063539_2013_0001_AC.pdf. Accessed 29 Nov 2018. 
12. Needham S, Funge-Smith S. The consumption of fish and fish products in the Asia-Pacific region based on household surveys. Bangkok: FAO Regional Office for Asia and the Pacific; 2015.

13. Lee NR. Estimating the effects of overweight duration, sodium intake and genetic variants on hypertension risk among Filipino women in Cebu, Philippines [dissertation]. U.S.A.: Department of Nutrition, University of North Carolina at Chapel Hill; 2009. https://core.ac.uk/download/pdf/210603231.pdf. Accessed 29 Nov 2019.

14. Mouritsen OG, Duelund L, Calleja G, Frost BM. Flavour of fermented fish, insect, game, and pea sauces: garum revisited. Int J Gastron Food Sci. 2017; 9:16-28. Doi: http://dx.doi.org/10.1016/j.ijgfs.2017.05.002.

15. Nakano M, Sagane Y, Koizumi R, Nakazawa Y, Yamazaki M, Watanabe T. et.al. Data on the chemical properties of commercial fish sauce products. Data Brief. 2017;15:658-64. Doi:10.1016/j.dib.2017.10.022.

16. Kobayashi M. Immunological functions of soy sauce: hypoallergenicity and antiallergic activity of soy sauce. J Biosci Bioeng. 2005;100:144-51. Doi:10.1263/jbb.100.144.

17. Kataoka S. Functional effects of Japanese style fermented soy sauce (shoyu) and its components. J Biosci Bioeng. 2005;100:227-34. Doi:10.1263/jbb.100.227.

18. Rezac S, Kok CR, Heermann M, Hutkins R. Fermented foods as a dietary source of live organisms. Front Microbiol. $2018 ; 9: 1785$. Doi:10.3389/fmicb.2018.01785.

19. Tamang JP, Shin D-H, Jung S-J, Chae S-W. Functional properties of microorganisms in fermented foods. Front Microbiol. $2016 ; 7: 758$. Doi:10.3389/fmicb.2016.00578.

20. Marco ML, Heeney D, Binda S, Cifalli CJ, Cotter PD, Foligne B. et.al. Health benefits of fermented foods: microbiota and beyond. Curr Opin Biotechnol. 2017;44:94-102. Doi:10.1016/j.copbio.2016.11.010.

21. Spohrer R, Larson M, Maurin C, Laillou A, Capanzana M, Garrett GS. The growing importance of staple foods and condiments used as ingredients in the food industry and implications for large-scale food fortification programs in Southeast Asia. Food Nutr Bull. 2013;34(2 Suppl):50-61. Doi:10.1177/15648265130342S107.

22. Garcia-Casal M, Pena-Rosas JP, Mclean M, De-Regil LM, Zamora G. and consultation working groups. Fortification of condiments with micronutrients in public health: from proof of concept to scaling up. Ann NY Acad Sci. 2016;1379:38-47. Doi:10.1111/nyas.13185.

23. Knowles J, van der Haar F, Shehata M, Gerasimov G, Bimo B, Cavenagh B. et.al. lodine intake through processed food: case studies from Egypt, Indonesia, the Philippines, the Russian Federation and Ukraine, 2010-2015. Nutrients. 2017;9:797. Doi:10.3390/nu9080797.

24. Degerud EM, Manger MS, Strand TA, Dierkes J. Bioavailability of iron, vitamin A, zinc, and folic acid when added to condiments and seasonings. Ann NY Acad Sci. 2015;1357:29-42. Doi:10.1111/nyas.12947.

25. JICA. Agricultural transformation and food security 2040. ASEAN region with a focus on Vietnam, Indonesia, and Philippines. Philippines country report. 2013. http://open_jicareport.jica.go.jp/pdf/12145553.pdf. Accessed 3 Dec 2018.

26. Pedro MRA, Benavides RC. Dietary changes and their health implications in the Philippines. In: The double burden of malnutrition. Case studies from six developing countries. Rome: Food and Agriculture Organization; 2006.

27. World Instant Noodles Association. Global demand for instant noodles. 2016 to 2020. 2021. https://instantnoodles.org/en/noodles/market.html. Accessed 6 June 2021.

28. Statista market forecast. Processed meat. Philippines. 2021 [cited 2021 June 6]. Available from https://www.statista.com/outlook/cmo/food/meat/processed-meat/philippines.

29. Ong MM, Ong RM, Reyes GK, Sumpaico-Tanchanco LB. Addressing the Covid-19 nutrition crisis in vulnerable communities: applying a primary care perspective. J Prim Care Community Health. 2020;11:1-4. Doi:10.1177/2150132720946951.

30. Food and Nutrition Research Institute-Department of Science and Technology (FNRI-DOST). Philippine Nutrition Facts and Figures 2013: Food Consumption Survey. Taguig City: FNRI-DOST; 2015.

31. FAO. INFOODs guidelines for food matching. Version 1.1. Food and Agriculture Organization; 2011.

32. FAO. Guidelines on the collection of information on food processing through food consumption surveys. Rome: Food and Agriculture Organization; 2015.

33. Fardet A, Rock E, Bassama J, Bohuon P, Prabhasankar P, Monteiro C. et.al. Current food classifications in epidemiological studies do not enable solid nutritional recommendations for preventing diet-related chronic diseases: the impact of food processing. Adv Nutr. 2015;6:629-38. Doi:10.3945/an.115.008789.

34. Fardet A, Rock E, Bassama J, Bohuon P, Prabhasankar P, Monteiro C, et.al. Current food classifications in epidemiological studies do not enable solid nutritional recommendations for preventing diet-related chronic diseases: the impact of food processing. Adv Nutr. 2015; 6:629-38. Doi: 10.3945/an.115.008789. 